\title{
HUBUNGAN KETERPAPARAN PORNOGRAFI MELALUI MEDIA DENGAN PERILAKU SEKSUAL REMAJA DI SMK BIT BINA AULIA
}

\section{Iis*}

\begin{abstract}
ABSTRAK
Perilaku seksual remaja akan mengakibatkan terjadinya seks bebas yaitu perilaku seksual yang tidak bertanggungjawab. Tujuan penelitian ini adalah untuk memperjelas dan memperdalam tentang hubungan keterpaparan pornografi melalui media dengan perilaku seksual remaja di SMK BIT Bina Aulia Kabupaten Bogor Tahun 2014. Metode penelitian ini adalah Survei analitik dengan pendekatan cross-sectional. Penelitian ini diambil dari seluruh siswa SMK BIT Bina Aulia Kabupaten Bogor tahun 2014. Hasil penelitian didapatkan bahwa siswa memiliki perilaku seksual berat 39,1\% dan terdapat hubungan yang signifikan antara keterpaparan pornografi melalui media, keterpaparan pornografi melalui handphone, keterpaparan pornografi melalui televisi dan keterpaparan pornografi melalui $\mathrm{dvd} / \mathrm{film}(\mathrm{p}<0,05)$ dengan perilaku seksual remaja.Variabel yang paling dominan mempengaruhi perilaku seksual adalah keterpaparan pornografi melalui dvd/film dengan OR 2,716 artinya siswa yang pernah melihat pornografi melalui dvd/film akan memiliki perilaku seksual berat 3 kali lebih besar dibandingkan dengan siswa yang tidak pernah melihat pornografi melalui dvd/film setelah di kontrol oleh variabel keterpaparan pornografi melalui televisi dan sikap orang tua.

Disarankan kepada Dinas Kesehatan/Puskesmas untuk lebih mensosialisasikan lagi tentang kegiatan Program Pelayanan Kesehatan Peduli Remaja (PKPR) sehingga menjadi wadah bagi remaja berkonsultasi mengenaii masalah kesehatan reproduksi. Kepada pihak sekolah diharapkan adanya kerjasama dengan orang tua siswa untuk lebih memberikan pengawasan terkait dengan semakin meluasnya pornografi termasuk dalam pengawasan terhadap pembelian kaset dvd/film.
\end{abstract}

Kata kunci : : Remaja, Perilaku Seksual, Pornografi, Media

\begin{abstract}
Adolescent sexual behavior will result in free sex is irresponsible sexual behavior. The purpose of this studyis to clarify and deepen your relationship with the media exposure of pornography through the sexual behavior of teenagers in vocational BIT Bina Aulia Bogor Regency 2014. This research method is analytic survey with a cross-sectional approach. Sampling was not performed in this study were drawn from all students of SMK Bina BIT Aulia Bogor district in 2014.The results showed that students $39.1 \%$ weight of sexual behavior and there is a significant relationship between exposure to pornography through the media, exposure to pornography through mobile phones, pornography exposure through television and exposure to pornography through the dvd/movie ( $\mathrm{p}$ 0.05) with adolescent sexual behavior. The most dominant variable affecting sexual behavior is exposure to pornography through the dvd/movie with OR 2,716 meaning that students who had seen pornography through the dvd/movie will have heavy sexual behavior 3 times greater than students who had never seen pornography via dvd/films after exposure variable controlled by pornography on television and the attitude of the parents.

Meaning that students who had seen pornography through the dvd/movie will have heavy sexual behavior 3 times greater than students who had never seen pornography via dvd/films after exposure variable controlled by pornography on television and the attitude of the parents.

To the school expected the cooperation with parents to provide supervision over related to the more widespread pornography included in the surveillance tapes to purchase $\mathrm{dvd} / \mathrm{movie}$.

Keywords : Adolescent, Sexual Behavior, Pornography, Media
\end{abstract}

* Staf Pengajar Program Studi D3 Kebidanan STIKes Cirebon 


\section{PENDAHULUAN}

Masa remaja merupakan proses tumbuh kembang peralihan dari kanak-kanak ke dewasa muda. Pada masa remaja terjadi perkembangan yang dinamis dalam kehidupan individu, ditandai dengan percepatan pertumbuhan fisik, emosional dan social ${ }^{1}$. Survei yang dilaksanakan di beberapa negara Asia Tenggara menunjukan bahwa proporsi perempuan yang melakukan hubungan seksual sebelum menikah cukup tinggi sementara di Amerika dengan subyek penelitian perempuan Afrika-Amerika berusia 14-18 tahun ditemukan 46\% responden melakukan hubungan seksual sama dengan 4 kali pada 6 bulan terakhir ${ }^{2}$.

Dalam Population Report 1985 menunjukkan bahwa 1-25\% remaja Indonesia telah melakukan hubungan seks pra nikah. Laporan dari jurnal ESCAP pada tahun 1992 menunjukkan bahwa di Indonesia satu dari lima perempuan yang statusnya menikah dalam usia 20-24 tahun telah melahirkan anak pertama yang merupakan buah hati dari hubungan seksual sebelum menikah ${ }^{3}$. Menurut data Kementerian Kesehatan RI Tahun 2013 persentase infeksi HIV, tahun 2010 pada rentang usia 15 - 19 tahun sebesar 827 kasus $(3,8 \%)$ dan rentang usia 20 - 24 tahun sebesar 3.480 kasus $(16,1 \%)$ dari total kasus 21. 591, Tahun 2011 usia 15 - 19 tahun sebesar 683 kasus $(3,2 \%)$ dan usia 20 - 24 tahun sebesar 3.113 kasus $(14,8 \%)$ dari total kasus 15.490 kasus. Tahun 2012 usia 15 - 19 tahun sebesar 697 kasus $(3,3 \%)$ dan usia 20 - 24 tahun sebesar 2.694 kasus $(14,1 \%)$ dari total kasus 15.133 kasus dan Tahun 2013 usia 15 - 19 tahun sebesar 163 kasus (3,0\%) dan usia 20 24 tahun sebesar 754 kasus $(14,0 \%)$ dari total kasus 5.369 kasus. Menurut data Kementerian Kesehatan RI Tahun 2013 jumlah AIDS di Jawa Barat tahun 1987 - 2009 sebesar 2.963 kasus, tahun 2010 sebesar 471 kasus, tahun 2011 sebesar 480 kasus, tahun 2012 sebesar 184 kasus dan tahun 2013 sebesar 33 kasus dengan total keseluruhan jumlah AIDS sebesar 4.131 kasus. Menurut Laporan Dinas Kesehatan Provinsi untuk Kota Bogor jumlah HIV tahun 2013 sebesar 271 kasus dan kumulatif AIDS sebesar 624 kasus ${ }^{4}$.

Berdasarkan hasil penelitian Taufik (2005), mengenai perilaku seksual remaja SMU di Surakarta dengan sampel berjumlah 1.250 orang, berasal dari 10 SMU di Surakarta yang terdiri dari 611 lakilaki dan 639 perempuan menyatakan bahwa sebagian besar remaja pernah melakukan ciuman bibir 10,53\%, melakukan ciuman dalam 5,6\%, melakukan onani atau masturbasi 4,23\% dan melakukan hubungan seksual sebanyak $3,09 \%^{2}$.

Berdasarkan hasil kegiatan Program Pelayanan Kesehatan Peduli Remaja (PKPR) Dinas Kesehatan Kabupaten Bogor Tahun 2013 didapatkan bahwa kejadian seks pra nikah usia 15-19 tahun pada perempuan berjumlah 22 orang, usia 10-14 tahun berjumlah 2 orang dan pada laki-laki usia 15-19 tahun berjumlah 10 orang dan usia 10-14 tahun berjumlah 2 orang. Jadi total 36 kasus. Untuk jumlah data tentang kehamilan tidak di inginkan pada perempuan usia 15-19 tahun berjumlah 29 orang dan usia 10-14 tahun sebesar 9 orang. Jadi total kasus 38 orang. Kemudian kejadian abortus pada perempuan usia 15-19 tahun sebesar 16 orang dan usia 10-14 tahun sebesar 1 orang, jadi total kasus 17 orang ${ }^{5}$.

Untuk data kejadian Infeksi Menular Seksual (IMS) pada remaja perempuan usia 15-19 tahun sebesar 50 orang dan usia 10-14 tahun sebesar 59 orang dan pada remaja laki-laki usia 15-19 tahun sebesar 63 orang dan usia 10-14 tahun sebesar 65 orang. Jadi total kasus 237orang. Untuk kejadian Infeksi saluran Reproduksi ( ISR) pada perempuan usia 15-19 tahun sebesar 65 orang dan usia 1014 tahun sebesar 31 orang dan pada remaja laki-laki usia 15-19 tahun sebesar 21 orang dan usia 1014 tahun sebesar 3 orang. Jadi total kasus 120 orang. Untuk kejadian HIV/AIDS pada perempuan usia 15-19 tahun sebesar 4 orang dan laki-laki usia 15-19 tahun sebesar 3 orang. Jadi total kasus 7 orang ${ }^{5}$.

Berdasarkan masalah tersebut maka dapat dikatakan bahwa kemungkinan akibat kurangnya pengetahuan seks dan informasi yang kurang tepat tentang seksualitas. Hal tersebut berdampak pada seks bebas yang keliru dan menyimpang dikalangan remaja.

\section{METODE PENELITIAN}

Rancangan penelitian ini adalah menggunakan jenis penelitian survei analitik dengan menggunakan metode cross sectional yaitu data tiap variabel dikumpulkan secara bersamaan. Populasi dalam 
penelitian ini adalah seluruh siswa SMK BIT Bina Aulia terdiri dari kelas X berjumlah 62 siswa, kelas XI berjumlah 56 siswa, kelas XII berjumlah 71 siswa jadi total 189 siswa. Tidak dilakukan pengambilan sampel dalam penelitian ini. Pengumpulan data dilaksanakan dengan menggunakan data primer dan instrumen yang digunakan kuesioner. Analisa yang digunakan analisa univariat, uji bivariat dan multivariat.

\section{HASIL PENELITIAN}

\section{Keterpaparan Pornografi Melalui Media}

Tabel 1. Distribusi Frekuensi siswa berdasarkan keterpaparan Pornografi Melalui Media

Distribusi Frekuensi Siswa Berdasarkan Keterpaparan Pornografi Melalui Media

\begin{tabular}{lcc}
\hline Keterpaparan pornografi & Jumlah $(\mathrm{n})$ & Persentase $(\%)$ \\
\hline Tidak terpapar & 12 & 6,9 \\
Terpapar & 162 & 93,1
\end{tabular}

Distribusi Frekuensi Siswa Berdasarkan Keterpaparan Pornografi Melalui Handphone

\begin{tabular}{lcc}
\hline Jenis media handphone & Jumlah $(\mathrm{n})$ & Persentase $(\%)$ \\
\hline Pernah & 122 & 70,1 \\
Tidak pernah & 52 & 29,9
\end{tabular}

Distribusi Frekuensi Siswa Berdasarkan Keterpaparan Pornografi Melalui Televisi

\begin{tabular}{lcc}
\hline Jenis media televisi & Jumlah $(\mathrm{n})$ & Persentase $(\%)$ \\
\hline Pernah & 120 & 69,0 \\
Tidak pernah & 54 & 31,0 \\
\hline
\end{tabular}

Distribusi Frekuensi Siswa Berdasarkan Keterpaparan Pornografi Melalui DVD/Film

\begin{tabular}{|c|c|c|}
\hline Jenis media dvd/film & Jumlah (n) & Persentase $(\%)$ \\
\hline Pernah & 47 & 27,0 \\
\hline Tidak pernah & 127 & 73,0 \\
\hline \multicolumn{3}{|c|}{ Distribusi Frekuensi Siswa Berdasarkan Sikap Orang Tua } \\
\hline Sikap orang tua & Jumlah (n) & Persentase $(\%)$ \\
\hline Tidak otoriter & 68 & 39,1 \\
\hline Otoriter & 106 & 60,9 \\
\hline
\end{tabular}

Berdasarkan tabel 1, siswa yang terpapar 162 siswa $(93,1 \%)$ lebih besar dibandingkan yang tidak terpapar 12 siswa $(6,9 \%)$. siswa yang pernah melihat pornografi melalui handphone 122 siswa $(70,1 \%)$ lebih besar dibandingkan siswa yang tidak pernah melihat pornografi melalui handphone 52 siswa $(29,9 \%)$, siswa yang pernah melihat pornografi melalui televisi 120 siswa $(69,0 \%)$ lebih besar dibandingkan siswa yang tidak pernah melihat pornografi melalui televisi 54 siswa $(31,0 \%)$. siswa yang tidak pernah melihat pornografi melalui dvd/film 127 siswa (73,0\%) lebih besar dibandingkan siswa yang pernah melihat pornografi melalui dvd/film 47 siswa (27,0\%). siswa yang sikap orangtua otoriter 106 siswa $(60,9 \%)$ lebih besar dibandingkan sikap orang tua tidak otoriter 68 siswa $(39,1 \%)$. 


\section{Perilaku Seksual Remaja}

Tabel 2. Distribusi Frekuensi Siswa Berdasarkan Perilaku Seksual Pada Remaja

\begin{tabular}{lcc}
\hline \multicolumn{1}{c}{ Perilaku seksual } & Jumlah $(\mathrm{n})$ & Persentase $(\%)$ \\
\hline Berisiko ringan & 106 & 60,9 \\
Berisiko berat & 68 & 39,1 \\
\hline Total & 174 & 100 \\
\hline
\end{tabular}

Berdasarkan tabel 2, siswa yang mempunyai perilaku seksual berisiko ringan 106 siswa (60,9\%) lebih besar dibandingkan siswa yang mempunyai perilaku seksual berisiko berat 68 siswa $(39,1 \%)$.

\section{Keterpaparan Pornografi Melalui Media dan Perilaku Seksual Remaja}

Tabel 3. Distribusi Siswa Berdasarkan Keterpaparan Pornografi Melalui Media dan Perilaku Seksual Remaja

\begin{tabular}{|c|c|c|c|c|c|c|c|c|}
\hline \multirow{3}{*}{$\begin{array}{l}\text { Keterpaparan } \\
\text { pornografi }\end{array}$} & \multicolumn{4}{|c|}{ Perilaku Seksual } & \multirow{2}{*}{\multicolumn{2}{|c|}{ Total }} & \multirow{3}{*}{$\mathrm{P}$ value } & \multirow{3}{*}{$\mathrm{OR}(95 \% \mathrm{CI})$} \\
\hline & \multicolumn{2}{|c|}{$\begin{array}{c}\text { Berisiko } \\
\text { ringan }\end{array}$} & \multicolumn{2}{|c|}{$\begin{array}{c}\text { Berisiko } \\
\text { berat }\end{array}$} & & & & \\
\hline & $\mathrm{n}$ & $\%$ & $\mathrm{n}$ & $\%$ & $\mathrm{n}$ & $\%$ & & \\
\hline Terpapar & 87 & 53,71 & 75 & 46,29 & 162 & 100 & & \\
\hline Tidak terpapar & 7 & 58,34 & 5 & 41,66 & 12 & 100 & 0,045 & $\begin{array}{c}2,190 \\
(1,076-4,455)\end{array}$ \\
\hline Total & 94 & 54,03 & 80 & 45,97 & 174 & 100 & & \\
\hline
\end{tabular}

Berdasarkan data tabel 3, diketahui bahwa siswa yang Terpapar akan memiliki perilaku seksual berat sebesar (46,29\%) dibandingkan yang tidak terpapar (41,66\%). Hasil uji statistik diperoleh nilai ( $\mathrm{p}$ value $=0.045$ ) yang berarti ada hubungan yang bermakna antara keterpaparan pornografi dengan perilaku seksual dan OR 2,190 artinya siswa yang terpapar akan memiliki perilaku seksual berisiko berat 2 kali lebih besar dibandingkan dengan siswa yang tidak terpapar.

Tabel 4. Distribusi Siswa Berdasarkan Keterpaparan Pornografi Melalui Handphone dan Perilaku Seksual Remaja

\begin{tabular}{|c|c|c|c|c|c|c|c|c|}
\hline \multirow{3}{*}{$\begin{array}{l}\text { Pornografi } \\
\text { melalui } \\
\text { handphone }\end{array}$} & \multicolumn{4}{|c|}{ Perilaku Seksual } & \multirow{2}{*}{\multicolumn{2}{|c|}{ Total }} & \multirow{3}{*}{$\begin{array}{l}\mathrm{P} \\
\text { Value }\end{array}$} & \multirow{3}{*}{$\begin{array}{l}\text { OR } \\
(95 \% \mathrm{CI}\end{array}$} \\
\hline & \multicolumn{2}{|c|}{ Berisiko ringan } & \multicolumn{2}{|c|}{ Berisiko berat } & & & & \\
\hline & $\mathrm{n}$ & $\%$ & $\mathrm{n}$ & $\%$ & $\mathrm{n}$ & $\%$ & & \\
\hline Tidak pernah & 38 & 73,1 & 14 & 26,9 & 52 & 100 & & 2,155 \\
\hline Pernah & 68 & 55,7 & 54 & 44,3 & 122 & 100 & 0,048 & $(1,060-4,381)$ \\
\hline Total & 106 & 60,9 & 68 & 39,1 & 174 & 100 & & \\
\hline
\end{tabular}

Berdasarkan data tabel 4, diketahui bahwa siswa yang pernah mengakses pornografi melalui handphone akan memiliki perilaku seksual berisiko berat sebesar $(44,3 \%)$ dibandingkan dengan yang tidak pernah mengakses pornografi melalui handphone (26,9\%). Hasil uji statistik diperoleh nilai (pvalue $=0,048$ ) yang berarti ada hubungan yang bermakna antara keterpaparan pornografi melalui handphone dengan perilaku seksual berisiko berat dan OR 2,155 artinya siswa yang pernah melihat pornografi melalui handphone akan memiliki perilaku seksual berisiko berat 2 kali lebih besar dibandingkan dengan yang tidak pernah melihat pornografi melalui handphone. 
Tabel 5. Distribusi Siswa Berdasarkan Keterpaparan Pornografi Melalui Televisi dan Perilaku Seksual Remaja

\begin{tabular}{|c|c|c|c|c|c|c|c|c|}
\hline \multirow{3}{*}{$\begin{array}{l}\text { Pornografi } \\
\text { melalui televisi }\end{array}$} & \multicolumn{4}{|c|}{ Perilaku Seksual } & & & \multirow{3}{*}{ P value } & \multirow{3}{*}{$\mathrm{OR}(95 \% \mathrm{CI})$} \\
\hline & \multicolumn{2}{|c|}{$\begin{array}{c}\text { Berisiko } \\
\text { ringan }\end{array}$} & \multicolumn{2}{|c|}{ Berisiko berat } & \multicolumn{2}{|c|}{ Total } & & \\
\hline & $\mathrm{n}$ & $\%$ & $\mathrm{n}$ & $\%$ & $\mathrm{n}$ & $\%$ & & \\
\hline Tidak pernah & 40 & 74,1 & 14 & 25,9 & 54 & 100 & & \\
\hline Pernah & 66 & 55,0 & 54 & 45,0 & 120 & 100 & 0,027 & $\begin{array}{c}2,338 \\
(1,153-4,740)\end{array}$ \\
\hline Total & 106 & 60,9 & 68 & 39,1 & 174 & 100 & & \\
\hline
\end{tabular}

Berdasarkan data tabel 5, diketahui bahwa siswa yang pernah melihat pornografi melalui televisi akan memiliki perilaku seksual berisiko berat sebesar $(45,0 \%)$ dibandingkan dengan yang tidak pernah melihat pornografi melalui televisi sebesar $(25,9 \%)$. Hasil uji statistik diperoleh nilai ( $\mathrm{P}$ value $=0,027$ ) yang berarti ada hubungan yang bermakna antara pornografi melalui media televisi dengan perilaku seksual dan OR 2,338 artinya siswa yang pernah melihat pornografi melalui televisi akan memiliki perilaku seksual berisiko berat 2 kali lebih besar dibandingkan dengan siswa yang tidak pernah melihat pornografi melalui televisi.

Tabel 6. Distribusi Siswa Berdasarkan Keterpaparan Pornografi Melalui DVD/Film dan Perilaku Seksual Remaja

\begin{tabular}{|c|c|c|c|c|c|c|c|c|}
\hline \multirow{3}{*}{$\begin{array}{l}\text { Pornografi } \\
\text { melalui } \\
\text { DVD/Film }\end{array}$} & \multicolumn{4}{|c|}{ Perilaku Seksual } & \multirow{2}{*}{\multicolumn{2}{|c|}{ Total }} & \multirow{3}{*}{$\mathrm{P}$ value } & \multirow{3}{*}{ OR $(95 \% \mathrm{CI})$} \\
\hline & \multicolumn{2}{|c|}{$\begin{array}{c}\text { Berisiko } \\
\text { ringan }\end{array}$} & \multicolumn{2}{|c|}{ Berisiko berat } & & & & \\
\hline & $\mathrm{n}$ & $\%$ & $\mathrm{n}$ & $\%$ & $\mathrm{n}$ & $\%$ & & \\
\hline Tidak pernah & 85 & 66,9 & 42 & 33,1 & 127 & 100 & & \\
\hline Pernah & 21 & 44,7 & 26 & 55,3 & 47 & 100 & 0,013 & $\begin{array}{c}2,506 \\
(1,265-4,964)\end{array}$ \\
\hline Total & 106 & 60,9 & 68 & 39,1 & 174 & 100 & & \\
\hline
\end{tabular}

Berdasarkan data tabel 6, diketahui bahwa siswa yang pernah melihat pornografi melalui dvd/film akan memiliki perilaku seksual berisiko berat sebesar $(55,3 \%)$ dibandingkan dengan yang tidak pernah melihat pornografi melalui dvd/film sebesar $(33,1 \%)$. Hasil uji statistik diperoleh nilai (P value $=0,013$ ) yang berarti ada hubungan yang bermakna antara keterpaparan pornografi melalui $\mathrm{dvd} /$ film dengan perilaku seksual dan OR 2,506 artinya siswa yang pernah melihat pornografi melalui dvd/film akan memiliki perilaku seksual berisiko berat 2 kali lebih dibandingkan dengan siswa yang tidak pernah melihat pornografi melalui $\mathrm{dvd} /$ film.

Tabel 7. Distribusi Siswa Berdasarkan Sikap Orang Tua dan Perilaku Seksual Remaja

\begin{tabular}{lcccccccc}
\hline $\begin{array}{l}\text { Sikap Orang } \\
\text { Tua }\end{array}$ & \multicolumn{3}{c}{ Perilaku Seksual } & & & \\
& \multicolumn{2}{c}{$\begin{array}{c}\text { Berisiko } \\
\text { ringan }\end{array}$} & \multicolumn{2}{c}{$\begin{array}{c}\text { Berisiko } \\
\text { berat }\end{array}$} & & Total & \multirow{2}{*}{ P value } & $\begin{array}{c}\text { OR (95\% } \\
\text { CI) }\end{array}$ \\
\cline { 2 - 7 } & $\mathrm{n}$ & $\%$ & $\mathrm{n}$ & $\%$ & $\mathrm{~N}$ & $\%$ & & \\
\hline Tidak otoriter & 35 & 51,5 & 33 & 48,5 & 68 & 100 & & \\
Otoriter & 71 & 67,0 & 35 & 33,0 & 106 & 100 & 0,059 & $\begin{array}{c}0,523 \\
(0,280-0,976)\end{array}$ \\
\hline Total & 106 & 60,9 & 68 & 39,1 & 174 & 100 & & \\
\hline
\end{tabular}


Berdasarkan data tabel 7, diketahui bahwa sikap orangtua tidak otoriter akan memiliki perilaku seksual berisiko berat sebesar $(48,5 \%)$ dibandingkan dengan sikap orangtua yang otoriter $(33 \%)$. Hasil uji statistik diperoleh nilai $\mathrm{P}$ value $=0,059$ yang berarti tidak ada hubungan yang bermakna antara sikap orang tua dengan perilaku seksual.

\section{Media yang Paling Berpengaruh terhadap Perilaku Seksual Remaja}

Tabel 8. Hasil Pemodelan Keterpaparan Pornografi Melalui Media Dengan Perilaku Seksual Remaja

\begin{tabular}{lccc}
\hline Variabel & P value & OR & 95\% Comfidence Interval \\
\hline $\begin{array}{l}\text { Keterpaparan pornografi } \\
\text { melalui media }\end{array}$ & 0,150 & 0,347 & $0,082-1,468$ \\
\hline $\begin{array}{l}\text { Keterpaparan pornografi } \\
\text { melalui handphone }\end{array}$ & 0,091 & 2,073 & $0,889-4,834$ \\
\hline $\begin{array}{l}\text { Keterpaparan melalui } \\
\text { televisi }\end{array}$ & 0,043 & 2,384 & $1,026-5,535$ \\
\hline Sikap orang tua & 0,039 & 0,453 & $0,213-0,962$ \\
\hline $\begin{array}{l}\text { Keterpaparan melalui } \\
\text { dvd/film }\end{array}$ & 0,038 & 2,716 & $1,056-6,986$ \\
\hline
\end{tabular}

Dari analisis multivariat didapatkan bahwa variabel yang signifikan berhubungan dengan perilaku seksual remaja ada 3 variabel yaitu keterpaparan pornografi melalui dvd/film, keterpaparan pornografi melalui televisi dan sikap orangtua. Variabel yang paling dominan berhubungan dengan perilaku seksual adalah keterpaparan pornografi melalui dvd/film dengan OR 2,716 artinya siswa yang pernah melihat pornografi melalui $\mathrm{dvd} /$ film memiliki perilaku seksual berisiko berat 3 kali lebih besar dibandingkan dengan siswa yang tidak melihat pornografi melalui dvd/film setelah dikontrol dengan variabel keterpaparan pornografi melalui televisi dan sikap orang tua.

\section{PEMBAHASAN}

\section{Hubungan Keterpaparan Pornografi Melalui Media dengan Perilaku Seksual Remaja}

Hasil analisis bivariat siswa yang terpapar akan memiliki perilaku seksual berat sebesar $(46,29 \%)$ dibandingkan yang tidak terpapar $(41,66 \%)$. Hasil uji statistik diperoleh nilai ( $\mathrm{p}$ value $=0,045$ ) yang berarti ada hubungan yang bermakna antara keterpaparan pornografi dengan perilaku seksual dan OR 2,190 artinya siswa yang terpapar akan memiliki perilaku seksual berisiko berat 2 kali lebih besar dibandingkan dengan yang tidak terpapar.

Hal ini sejalan dengan penelitian yang dilakukan Euis dan Sandra (2008) menyebutkan bahwa sebanyak (83.8\%) siswa telah mendapatkan pengalaman mendapatkan pornografi (terpapar). Sebagian besar (55.2\%) dari yang Terpapar, mendapatkan pornografi melalui media yaitu cetak dan elektronik ${ }^{6}$.

Berdasarkan analisis bivariat menunjukkan siswa yang pernah mengakses pornografi melalui handpone akan memiliki perilaku seksual berisiko berat sebesar $(44,3 \%)$ dibandingkan dengan yang tidak pernah mengakses pornografi melalui handpone (26,9\%). Pada penelitian ini Hasil uji statistik diperoleh nilai ( $\mathrm{p}$ value $=0,048$ ) yang berarti ada hubungan yang bermakna antara pornografi melalui media handphone dan OR 2,155 artinya siswa yang pernah melihat pornografi melalui handpone akan memiliki perilaku seksual berisiko berat 2 kali lebih besar dibandingkan dengan yang tidak pernah melihat pornografi melalui handpone.

Hal ini disebabkan karena handphone merupakan suatu alat komunikasi yang digunakan sebagai perangkat telekomunikasi konvensional saluran tetap, namun dapat dibawa kemana-mana dan tidak perlu disambungkan dengan jaringan telepon menggunakan kabel (nirkabel; wireless). Selain berfungsi untuk melakukan dan menerima panggilan telepon, ponsel umumnya juga berfungsi sebagai pengiriman dan penerimaan pesan singkat (short message service, SMS) yang banyak digunakan oleh sebagian besar masyarakat termasuk oleh remaja ${ }^{7}$. 
Menurut Buvee (1997) bahwa media adalah sebuah alat yang mempunyai fungsi menyampaikan pesan. Sedangkan Suparman (1997) mengemukakan media adalah alat yang digunakan untuk menyalurkan pesan atau informasi dari pengirim kepada penerima pesan. Pengiriman dan penerimaan pesan itu dapat berbentuk orang atau lembaga. Sedangkan media tersebut dapat berupa alat-alat elektronik, gambar, buku dan sebagainya ${ }^{7}$. Selanjutnya Irawan dan Prastati (1996) mengemukakan media adalah perantara atau apa saja yang dapat menyalurkan informasi dari sumber informasi ke penerima informasi.

Kemudian faktor yang mempengaruhi perilaku seksual selanjutnya adalah keterpaparan pornografi melalui televisi $(69,0 \%)$ dan analisis bivariat didapatkan siswa yang memiliki perilaku seksual berat pernah melihat televisi yang berisikan pornografi sebesar (45\%). Hasil uji statistik terdapat hubungan yang signifikan antara keterpaparan melalui televisi dengan perilaku seksual ( $\mathrm{p}$ value 0,027 ) dan OR 2,338 artinya siswa yang pernah melihat pornografi melalui televisi akan memiliki perilaku seksual berisiko berat 2 kali lebih besar dibandingkan dengan siswa yang tidak melihat pornografi melalui televisi.

Televisi merupakan media massa yang sangat populer di masyarakat dibandingkan dengan media lainnya. Perkembangan pertelevisian di Indonesia sudah sedemikian tinggi sehingga mampu mengubah pola fikir dan nilai-nilai di masyarakat. Kebebasan berekspresi telah memberi dampak negatif pada sejumlah stasiun televisi di Indonesia. Tayangan berbau seks dan pornografi banyak ditayangkan ditelevisi terutama yang menjadi sasaran targetnya adalah pada remaja, dimana fase ini ada fase yang berusaha untuk mencari jati diri dan berusaha meniru orang lain.

Menurut Redatin (2005), sebanyak 85,87\% responden tergolong sering menonton acara televisi. Acara yang ditonton khususnya dalam menonton film yang mengandung unsur seks. Hasil penelitian menunjukkan $72 \%$ responden memiliki frekuensi menonton adegan seks yang tergolong tinggi. Meskipun responden umumnya merasakan/mengerti bahwa acara televisi dapat mempengaruhi mereka, namun kenyataannya mereka tetap menyukainya yaitu sebesar $(75,73 \%)^{8}$. Hal ini diperlukan bimbingan dan peran orangtua ketika remaja mulai menonton acara televisi.

Kemudian faktor yang mempengaruhi perilaku seksual selanjutnya adalah keterpaparan pornografi melalui dvd/film sebesar $27 \%$ dan akan memiliki perilaku seksual berisiko berat 55,3\%. Hasil uji statistik terdapat hubungan yang signifikan antara keterpaparan melalui dvd/film dengan perilaku seksual didapatkan ( $\mathrm{p}$ value 0.013 ) dan OR 2,506 artinya siswa yang pernah melihat pornografi melalui dvd/film akan memiliki perilaku seksual berisiko berat 2 kali lebih besar dibandingkan dengan siswa yang tidak pernah melihat pornografi melalui dvd/film. Hal ini disebabkan oleh $\mathrm{dvd} /$ film berperan sebagai sarana baru yang digunakan untuk menyebarkan hiburan yang sudah menjadi kebiasaan terdahulu, serta menyajikan cerita, peristiwa, musik, drama, lawak dan sajian teknis lainnya kepada masyarakat umum ${ }^{9}$.

Dari segi komunikasi, ide atau pesan yang dibungkus oleh cerita atau film merupakan pendekatan yang bersifat membujuk (persuasive). Banyak remaja belajar tentang perilaku seksual dari menonton film termasuk menonton film yang berisikan pornografi. Menurut Mulyana (2004) mengatakan bahwa film berpengaruh pada sikap dengan cara memperteguh, menciptakan dan mengubah norma karena film merupakan cermin / jendela masyarakat dimana media massa itu berada. Perilaku menonton film yang berisikan pornografi dipengaruhi oleh intensitas menonton film, jenis media film dan akses terhadap film ${ }^{10}$.

\section{Hubungan Sikap Orangtua dengan Perilaku Seksual Remaja}

Hasil analisis univariat menunjukkan bahwa sebanyak 106 siswa $(60,9 \%)$ sikap orangtua otoriter sedangkan sebanyak 68 siswa $(39,1 \%)$ sikap orang tua tidak otoriter. Hasil analisis bivariat menunjukkan sikap orangtua tidak otoriter akan memiliki perilaku seksual berisiko berat sebesar (48.5\%) dibandingkan dengan sikap orangtua yang otoriter (33\%). Dari 4 item pertanyaan tentang sikap orang tua, siswa yang menjawab ya ketika orangtua melarang keras untuk bergaul dengan teman $(62,07 \%)$, orang tua melarang bertanya tentang pendidikan seks $(65,52 \%)$, orang tua melarang anaknya berpacaran $(56,90 \%)$ dan orang tua menghukum anaknya ketika ketahuan 
menonton film porno $(43,10 \%)$. Hal ini menunjukkan sikap orang tua masih tabu untuk memperkenalkan pendidikan seksual pada anaknya.

Hasil penelitian ini sejalan dengan penelitian yang dilakukan Sekarrini (2012) yang menunjukkan sikap orangtua demokratis sebanyak (53\%) dan Sikap orangtua Permisif (bebas tanpa batas) sebanyak (45\%). Dari hasil analisis bivariat didapatkan bahwa responden dengan pola asuh permisif (bebas tanpa batas) memiliki presentase perilaku seksual berat sebesar $(50 \%)^{11}$.

Menurut Soejiningsih (2004), sikap orang tua atau pola asuh adalah suatu model atau cara mendidik anak yang merupakan suatu kewajiban dari setiap orangtua dalam usaha membentuk priabadi anak yang sesuai dengan harapan masyarakat pada umunnya ${ }^{12}$.

\section{SIMPULAN}

Dari hasil penelitian tentang "Hubungan Keterpaparan Pornografi Melalui Media dengan Perilaku Seksual Remaja di SMK BIT Bina Aulia kabupaten Bogor Tahun 2014” dapat disimpulkan bahwa:

1. Siswa memiliki perilaku seksual berat $39,1 \%$, media elektronik yang terbanyak digunakan (handpone $70,1 \%$, televisi $69 \%$ dan dvd/film $27,0 \%$ ), sikap orang tua otoriter $60,9 \%$.

2. Ada hubungan yang signifikan antara perilaku seksual remaja dengan keterpaparan pornografi melalui media handphone, televisi, dvd/film.

3. Variabel yang paling dominan berhubungan dengan perilaku seksual adalah keterpaparan pornografi melalui dvd/film dengan OR 2,716. Artinya siswa yang pernah melihat pornografi melalui dvd/film memiliki perilaku seksual berisiko berat 3 kali lebih besar dibandingkan dengan siswa yang tidak terpapar pornografi melalui dvd/film.

\section{SARAN}

\section{Bagi Dinas Kesehatan Kabupaten Bogor}

Diharapkan dapat memberikan pengawasan pada puskesmas yang sudah mempunyai kegiatan PKPR (Kegiatan Program Pelayanan Kesehatan Peduli Remaja) sehingga program tersebut bisa berjalan dengan baik.

\section{Bagi Dinas pendidikan}

Diharapkan dapat melakukan penetapan kurikulum/muatan lokal tentang kesehatan reproduksi yang komprehensif sehingga remaja dapat lebih memahami tentang kesehatan reproduksi dengan benar.

\section{Dinas Informasi dan Komunikasi Kabupaten Bogor}

Dapat melaksanakan Undang-undang pornografi dengan tegas terhadap media cetak maupun elektronik yang melakukan terhadap pelanggaran tersebut termasuk dalam menekan penyebaran pornografi melalui dvd/film.

\section{Puskesmas}

Diharapakan dapat lebih mengembangkan lagi tentang Kegiatan Program Pelayanan Kesehatan Peduli Remaja (PKPR) dan bisa setiap bulannya melakukan penyuluhan ke sekolah-sekolah sehingga menjadi wadah remaja untuk berkonsultasi mengenai masalah kesehatan reproduksi remaja.

\section{Bagi SMK BIT Bina Aulia}

1) Diharapkan Kepala Sekolah melakukan kerjasama lintas sektor dengan pemerintah terkait seperti Puskesmas, Dinas Kesehatan dan LSM lainnya yang dapat membantu memberikan penyuluhan disekolah terkait tentang kesehatan reproduksi

2) Kepala Sekolah dan Guru melakukan adanya kerjasama dengan orang tua siswa untuk lebih memberikan pengawasan terkait dengan semakin meluasnya pornografi termasuk dalam pengawasan terhadap pembelian kaset $\mathrm{dvd} /$ film

3) Kepala Sekolah dan Guru melakukan adanya kontrol tentang penyebaran media pornografi khususnya penggunaan media cetak dan elektronik diantaranya dengan melakukan razia setiap bulannya 


\section{Bagi Peneliti selanjutnya}

1) Diharapkan dapat meneliti lebih lanjut lagi tentang sikap orang tua yang bisa menekan terjadinya perilaku berisiko pada remaja.

2) Untuk status ekonomi pengukuran diharapkan bisa langsung ditanyakan pada orang tua siswa, ketika status ekonomi di tanyakan pada siswa diharapkan dalam bentuk pemberian uang jajan /bulan.

3) Diharapkan dapat melakukan penelitian lagi tentang jenis film yang dapat menyebabkan terjadinya perilaku seksual berisiko pada remaja.

\section{DAFTAR PUSTAKA}

1. Sarwono,W.S. Psikologi Remaja Edisi Revisi. Jakarta: PT Raja Grafindo Persada; 2012

2. Taufik dan Anganthi, N.R.N. Seksualitas Remaja : Perbedaan Seksualitas Antara Remaja Yang Tidak Melakukan Hubungan Seksual Dan Remaja Yang Melakukan Hubungan Seksual. Jurnal Penelitian Humaniora, Vol 6, No 2, 2005.

3. Azinar, Muhammad. Perilaku Seksual Pranikah Berisiko Terhadap Kehamilan Tidak Diinginkan. Jurnal Kesehatan Masyarakat. Universitas Negeri Semarang; 2013

4. Kementerian Kesehatan RI. Laporan Situasi Perkembangan HIV/AIDS di Indonesia. 2013

5. Hasil kegiatan Program Pelayanan Kesehatan Peduli Remaja (PKPR). Dinas Kesehatan Kabupaten Bogor Tahun 2013

6. Euis,Sandra. Efek Paparan Pornografi Pada Remaja SMP negeri Kota Pontianak Tahun 2008. Jurnal Makara, Seri Sosial Humaniora, Vol. 13, No. 1, JULI 2009: 48-56; Universitas Indonesia;2008

7. Papu J. Situs Porno dan Kesehatan Mental (Diakses : http : //epsikologi.com. diakses tanggal 12 Januari 2014);2001

8. Parwadi, Redatri. Potret Penggunaan Media Televisi pada Kalangan Remaja Menuju Dewasa Awal di Yogyakarta. 2005.

9. Jufri, M. Intensitas Mengakses Situs Seksual dan Permisifitas Perilaku Seksual Remaja. 2005 (http : //www.bkkbn.go.id. diakses 12 Januari 2014)

10. Mulyana, Deddy. Ilmu Komunikasi Suatu Pengantar. Bandung : PT Remaja Rosada Karya; 2004.

11. Sekarrini, Loveria. Faktor - Faktor yang Berhubungan dengan Perilaku Seksual Remaja di SMK Kesehatan di Kabupaten Bogor Tahun 2011. Skripsi. Program Pasca Sarjana Kesehatan Masyarakat. Depok. Depok: FKM UI; 2011

12. Soetjiningsih .Tumbuh Kembang Remaja dan Permasalahannya. Jakarta: Sagung Seto; 2004 